International Journal of Software Engineering \& Applications (IJSEA), Vol.7, No.4, July 2016

\title{
TOWARDS A NEW METHODOLOGY FOR WEB GIS DEVELOPMENT
}

\author{
Fanon Ananda ${ }^{1}$, Prof. David Kuria ${ }^{2}$ and Dr. Moses Ngigi ${ }^{3}$ \\ ${ }^{1}$ Department of Geomatic Engineering and Geospatial Information Systems, Jomo \\ Kenyatta University of Agriculture and Technology, Nairobi, Kenya \\ ${ }^{2}$ Institute of Geomatics, GIS and Remote Sensing (IGGReS), Dedan Kimathi University, \\ Nyeri, Kenya \\ ${ }^{3}$ Institute of Geomatics, GIS and Remote Sensing (IGGReS), Dedan Kimathi University, \\ Nyeri, Kenya
}

\begin{abstract}
There has been an increasing need for geospatial information that is delivered through internet technologies. This broad category of systems is referred to as Web Geographic Information Systems (Web GIS). These systems exhibit characteristics common to both stand-alone and web-based systems making it necessary to apply a hybrid methodology during their development. This paper proposes a methodology for developing Web GIS that is herein referred to as the Y-Model Web GIS Development Methodology (YWDM) which has been adapted from existing software development methodologies and applied to the context of Web GIS development. The paper outlines in details the phases of the methodology. Its viability as a methodology has been tested through its use in the implementation of the Emuhaya Web GIS portal. The methodology presented here is not intended to be a rigid guide for web GIS development but instead it provides a useful framework for guiding the process.
\end{abstract}

\section{KEYWORDS}

Geographic Information Systems, Web Development, Methodology, Web Requirements, Web GIS

\section{INTRODUCTION}

There has been a significant increase in the use of Geographic Information Systems (GIS) over the last decade [1]. GIS refers to a powerful set of computer-based tools used to collect, store, manipulate, analyze and display spatially referenced information. GIS are remarkably useful in planning, data analysis and decision-making. [2] identifies GIS as "a computing application capable of creating, storing, manipulating, visualizing and analyzing geographic information". A GIS is composed of the following major components; People who are the users of the system; applications comprising of the processes and programs; data and information; the core GIS software and Hardware [3]. Alternatively the components of a GIS can also be examined using

DOI : 10.5121/ijsea.2016.7405 
International Journal of Software Engineering \& Applications (IJSEA), Vol.7, No.4, July 2016

the 3-tier perspective; A component to collect geographic data into the GIS either from remote sensing sources, field surveys, printed and digital maps; a database component that allows the storage and manipulation of spatial data and finally a presentation component that brings together themes or layers of data for a number of spatial analytical operations [4]. The final outcome of the analysis operations in a GIS is disseminated in a number of ways but notably the most common is in the form of maps.

The ever increasing dependency on the Internet and the World Wide Web technologies has led to the development of web applications known as the Web GIS. Essentially they are an extension of conventional GIS to offer different services for analysis and visualization of geographical information on the Web [5]. These systems exhibit different characteristics from conventional systems such as rapidly changing technologies, increased emphasis on user interface and short time frames for initial delivery [6]. It is therefore important to examine the development process of such systems to ensure it encompasses the characteristics of geographic information processing while being available on the Web. Furthermore the development of this systems requires a multidisciplinary approach as they handle information in very many formats (audio,video,text,graphics). Multiple disciplines such as HCI, graphics design and networking play a significant role in the development of web systems [7]. The core component of any webbased GIS is the mapping and visualization technology. Rapid evolution of web mapping technologies has resulted in a number of benefits/advantages; provision for rich mapping and imagery, increased scalability, improved map services designed for the web, reduced learning times for non-technical users, and improved data management. Most web mapping solutions take advantage of hybrid raster/vector approaches. Vector data consists of 3 primitives; lines, points and polygons while raster data consists of raster imagery like aerial imagery and satellite imagery $[8]$.

Despite the differences between web systems and conventional software applications, there are quite a number of similarities which include; need for methodologies, need for requirements elicitation, involves programming, testing and maintenance. Consequently it is important to apply formal tools and methodologies to support the rapid development of web systems that meet changing business needs. Rapid changes in web technologies and systems have resulted in the emergence of Web engineering as a discipline. Web Engineering is the application of systematic, disciplined and quantifiable approaches to development, operation and maintenance of web-based applications [7]. The emergence of this discipline served as a remedy to the chaotic and adhoc development approaches witnessed in earlier web applications. Furthermore there was increasing pressure on developers to build high quality applications within short intervals with few formal web development methodologies to choose from as a means of support [9]. This paper focuses on tools and methodologies to support the rapid development of Web GIS applications.

The paper is structured as follows; The next section presents the problem statement followed by a review of existing methodologies for conventional, web, GIS and Web GIS systems. The section after introduces the approach used to create the hybrid methodology and the details of the hybrid YWDM. The last section contains an evaluation of the proposed methodology using a common framework and concludes with some observations concerning the use and adoption of the methodology. 
International Journal of Software Engineering \& Applications (IJSEA), Vol.7, No.4, July 2016

\subsection{Problem Statement}

Despite having been in existence for over two decades, systems development methodologies have been continuously evolving to accommodate changing technologies and development techniques. Web GIS are such emerging systems that have recently advanced to allow both the geospatial data and software to be accessed and applied remotely through the internet and web technologies unlike in conventional GIS. During a recent development of a Web GIS for cultural and natural resource information management, the researchers encountered a gap in the academic discourse on the available web GIS development methodologies. There lacked a generic framework that can be adopted for most web GIS development projects despite of the project's scope and team capabilities. Most of the available documented methodologies are impractical to the novice developer working on small to medium sized projects which represent the majority due to their complex technical steps which are not easy to understand if you lack a software engineering background. This has presented the researchers with an opportunity to initiate dialogue on a generic Web GIS methodology by investigating, identifying, applying and documenting the necessary development activities applicable to all such projects.

\subsection{Justification}

The vision of distributed GIS has been advancing rapidly in the recent past and there is increasingly a need for a generic methodology for Web GIS development . A further advancement in technology has seen these systems being deployed on cloud based platforms which further complicates their development process/needs. On the other hand, smart mobile devices with increased functionality have also become ubiquitous and we are now witnessing as Web GIS's are now migrating onto these platforms which also poses additional challenges on the current development methodologies. It is thus important for scholars of systems development methodologies to critically review the current available methodologies with a view of

recommending refined approaches that meet current technology changes and business requirements.

\section{Development Methodologies RevieW}

\subsection{Conventional Systems Development Methodologies}

A system development methodology refers to a collection of procedures, techniques, tools and documentation aids to assist system developers in their efforts to implement new information systems [10]. A methodology consists of clearly defined phases to guide developers throughout the project. Methodologies are important because they standardize the development process resulting in a better software product. Systems development methodologies have been in existence since the early $70 \mathrm{~s}$ and were initially intended for use on centralized systems. Table 1 shows some of the methodologies in the market but this is not a detailed list as the focus of this paper is not to conduct a comprehensive review of development methodologies but to provide a brief view that will enable us conceptualize the need for the methodology proposed later in the paper. 
International Journal of Software Engineering \& Applications (IJSEA), Vol.7, No.4, July 2016

Table 1: Conventional Systems Development Methodologies

\begin{tabular}{|c|c|c|}
\hline Methodology & Description & Strengths/weaknesses \\
\hline $\begin{array}{l}\text { Waterfall } \\
\text { model }\end{array}$ & $\begin{array}{l}\text { Rigid model suitable for stable projects } \\
\text { whose requirements will rarely change } \\
\text { throughout the lifetime of the project } \\
{[10] \text {. }}\end{array}$ & $\begin{array}{l}\text { This is a easy to use model } \\
\text { that has clearly defined } \\
\text { milestones that the } \\
\text { development team can } \\
\text { understand. However the } \\
\text { model assumes that the user } \\
\text { requirements are frozen in } \\
\text { time and thus doesn't } \\
\text { accommodate any changes. }\end{array}$ \\
\hline Prototyping & $\begin{array}{l}\text { Well adapted to interactive applications. } \\
\text { User involvement/feedback is key to the } \\
\text { success of the process. It results in } \\
\text { several system versions with different } \\
\text { levels of functionality [11]. }\end{array}$ & $\begin{array}{l}\text { Increased user involvement } \\
\text { better refines the } \\
\text { requirements } \\
\text { incorporates user changes } \\
\text { earlier in the development } \\
\text { process. However a key } \\
\text { limitation is loss of key } \\
\text { objectives due to insufficient } \\
\text { analysis by developers as } \\
\text { they focus on prototype } \\
\text { objectives. }\end{array}$ \\
\hline $\begin{array}{l}\text { Structured } \\
\text { Systems } \\
\text { Analysis \& } \\
\text { Design } \\
\text { Methodology } \\
\text { (SSADM) }\end{array}$ & $\begin{array}{l}\text { Suitable for large projects. It puts a lot } \\
\text { of emphasis on analysis and design } \\
\text { activities. It outlines strict rules and } \\
\text { guidelines throughout the process [12]. }\end{array}$ & $\begin{array}{l}\text { This methodology provides a } \\
\text { formal and detailed approach } \\
\text { that guarantees the use of } \\
\text { thorough analysis and design } \\
\text { approaches to ensure all user } \\
\text { requirements are met. As a } \\
\text { result of its great focus on } \\
\text { detail, the methodology is } \\
\text { time consuming and costly. }\end{array}$ \\
\hline Spiral Model & $\begin{array}{l}\text { Risk driven cyclic approach to software } \\
\text { development [13]. }\end{array}$ & $\begin{array}{l}\text { This model has a great } \\
\text { amount of risk analysis and } \\
\text { is thus suitable for large and } \\
\text { mission critical projects. } \\
\text { However the risk analysis } \\
\text { phase is the most arduous } \\
\text { and requires specific } \\
\text { expertise as the success of } \\
\text { the project is greatly affected } \\
\text { by the outcome of this phase. }\end{array}$ \\
\hline
\end{tabular}


International Journal of Software Engineering \& Applications (IJSEA), Vol.7, No.4, July 2016

\begin{tabular}{|c|c|c|}
\hline $\begin{array}{l}\text { James } \\
\text { Martin's } \\
\text { Rapid } \\
\text { Applications } \\
\text { Development } \\
\text { (RAD) }\end{array}$ & $\begin{array}{l}\text { Emphasizes the delivery of functional } \\
\text { products within the shortest time } \\
\text { possible in line with the changing } \\
\text { business needs. It was developed in an } \\
\text { attempt to reduce long development } \\
\text { lead times while guaranteeing earlier } \\
\text { product payback with more payback } \\
\text { time before change in technology makes } \\
\text { the product obsolete. It also emphasizes } \\
\text { high stakeholder participation [10]. }\end{array}$ & $\begin{array}{l}\text { It encourages customer } \\
\text { involvement and shortened } \\
\text { development times. However } \\
\text { it is only suitable for systems } \\
\text { that can be modularized. The } \\
\text { model also relies on highly } \\
\text { skilled designers and } \\
\text { developers and is not suitable } \\
\text { for small projects as it is } \\
\text { quite costly. }\end{array}$ \\
\hline $\begin{array}{l}\text { Agile } \\
\text { development } \\
\text { methodologies }\end{array}$ & $\begin{array}{l}\text { This are considered as the newest } \\
\text { software development methodologies as } \\
\text { they emerged in the mid 90s. They have } \\
\text { been designed to address the problem of } \\
\text { delivering high-quality software on time } \\
\text { under constantly and rapidly changing } \\
\text { requirements in business and IT } \\
\text { environments. Some of the general } \\
\text { methods that fall in this category are; } \\
\text { Extreme Programming (XP), Scrum, } \\
\text { Crystal, Dynamic Systems Development } \\
\text { Method (DSDM), Adaptive Software } \\
\text { Development (ASD), Feature-Driven } \\
\text { Development (FDD), Lean Software } \\
\text { Development (LSD), Agile Modeling } \\
\text { (AM),and Agile Unified Process (AUP) } \\
\text { [14]. }\end{array}$ & $\begin{array}{l}\text { Short product delivery times } \\
\text { and customer involvement is } \\
\text { at the center of this approach } \\
\text { which makes it really flexible } \\
\text { in accommodating changes } \\
\text { and evaluating project } \\
\text { priorities. It is important to } \\
\text { mention that the } \\
\text { methodology also encourages } \\
\text { people creativity over } \\
\text { policies and procedures. } \\
\text { However the project requires } \\
\text { an experienced project } \\
\text { manager especially when it } \\
\text { comes to coordinating large } \\
\text { project teams as the final } \\
\text { product may deviate from the } \\
\text { initial intended expectations }\end{array}$ \\
\hline
\end{tabular}

Systems development methodologies have been evolving over the years to adapt to the changing needs of software projects. Each methodology has strengths and weaknesses that tend to make it favorable for specific types of projects. Similarly with the evolution in complexity and needs of web applications, new methodologies specific to web systems have also been developed. However the technologies and needs of web systems have been changing rapidly which has resulted in new project specific methodologies being developed and documented. These new methodologies provide frameworks that can be adapted to future web projects.

Web GIS are systems that exhibit both GIS and web characteristics. More specifically Web GIS are concerned with mapping and visualization of geographical information on a web platform. In order to propose a suitable Web GIS development methodology it is necessary to dissect the already existing methodologies for web and GIS development and their suitability for modern Web GIS projects. 
International Journal of Software Engineering \& Applications (IJSEA), Vol.7, No.4, July 2016

\subsection{Web Development Methodologies}

With most modern systems being distributed over the web, there has been an increase in the number of methodologies proposed to support the complexity of web application development [15]. These methodologies have varying phases with some common underlying features. Table 2 provides a summary of common web development methodologies currently in use. Some elements of the framework proposed by Avison and Fitzgerald [10] are used in the evaluation of the listed methodologies.

Table 2: Web Development Methodologies

\begin{tabular}{|c|c|c|}
\hline Methodology & Overview & Strengths/Weaknesses \\
\hline $\begin{array}{l}\text { Web } \\
\text { Information } \\
\text { Systems } \\
\text { Development } \\
\text { Methodology } \\
\text { (WISDM) }\end{array}$ & $\begin{array}{l}\text { Modern approach to web development } \\
\text { that focuses on the wider aspects of web- } \\
\text { based information systems. It blends } \\
\text { together website development techniques } \\
\text { and traditional IS development } \\
\text { competencies in database and program } \\
\text { design. Its major phases are } \\
\text { organizational analysis information } \\
\text { analysis, technical design, HCI and Work } \\
\text { design. There is no arrangement/ordering } \\
\text { of the phases. Appropriate emphasis is } \\
\text { placed on each during the project lifetime } \\
\text { [10]. }\end{array}$ & $\begin{array}{l}\text { The methodology provides a } \\
\text { multiview approach to web } \\
\text { development focusing on } \\
\text { Organizational analysis, } \\
\text { Information analysis, Technical } \\
\text { design, Human computer } \\
\text { interaction and Work design. It } \\
\text { is suitable for all project } \\
\text { scopes. Unlike conventional } \\
\text { methodologies there is no a } \\
\text { priori ordering the five aspects } \\
\text { but instead each is emphasized } \\
\text { separately [10,16]. }\end{array}$ \\
\hline $\begin{array}{l}\text { Internet } \\
\text { Commerce } \\
\text { Development } \\
\text { Methodology } \\
\text { (ICDM) }\end{array}$ & $\begin{array}{l}\text { This is highly adapted for e-commerce } \\
\text { application. Business focus is at the core } \\
\text { of this methodology. It provides a } \\
\text { management and business strategy driven } \\
\text { by the business needs. This methodology } \\
\text { has been thoroughly presented by [17]. }\end{array}$ & $\begin{array}{l}\text { The methodology considers } \\
\text { evolutionary development of } \\
\text { systems, provides a business } \\
\text { and strategic focus and includes } \\
\text { a management structure in } \\
\text { addition to covering the } \\
\text { engineering aspects of Web } \\
\text { application development. } \\
\text { However the methodology is } \\
\text { fairly complex lacks } \\
\text { sufficiently flexible guidelines } \\
\text { taking into consideration the } \\
\text { industry specific factors [18]. }\end{array}$ \\
\hline $\begin{array}{l}\text { UML-based } \\
\text { Web } \\
\text { Engineering } \\
\text { (UWE) }\end{array}$ & $\begin{array}{l}\text { Methodology based on the unified } \\
\text { process. It is a model-driven approach } \\
\text { that emphasizes the use of standard } \\
\text { analysis and design models for web } \\
\text { systems. The focus of the process is on } \\
\text { adaptive applications with changing user }\end{array}$ & $\begin{array}{l}\text { UWE is continuously adapting, } \\
\text { to new features of Web } \\
\text { systems, such as more } \\
\text { transaction-based, personalized, } \\
\text { context-dependent, r and } \\
\text { asynchronous applications and }\end{array}$ \\
\hline
\end{tabular}


International Journal of Software Engineering \& Applications (IJSEA), Vol.7, No.4, July 2016

\begin{tabular}{|c|c|c|}
\hline & and technology requirements $[19,20,21]$. & $\begin{array}{l}\text { more generally, UWE evolves } \\
\text { to incorporate the state of the } \\
\text { art of software engineering } \\
\text { techniques. A major limitation } \\
\text { is that UWE does not allow } \\
\text { dealing with all different parts } \\
\text { of a web application in terms of } \\
\text { its content, hypertext and } \\
\text { presentation levels and their } \\
\text { structural and behavioural } \\
\text { features [22]. }\end{array}$ \\
\hline $\begin{array}{l}\text { Web } \\
\text { Modeling } \\
\text { Language } \\
\text { (WebML) }\end{array}$ & $\begin{array}{l}\text { This is an iterative methodology inspired } \\
\text { by Boehm's spiral model. With every } \\
\text { iteration the new version of the } \\
\text { application is tested for conformance to } \\
\text { existing and new requirements }[19,20] \text {. } \\
\text { WebML enables the high-level } \\
\text { description of a Web site under distinct } \\
\text { orthogonal dimensions: its data content } \\
\text { (structural model), the pages that } \\
\text { compose it (composition model), the } \\
\text { topology of links between pages } \\
\text { (navigation model), the layout and } \\
\text { graphic requirements for page rendering } \\
\text { (presentation model), and the } \\
\text { customization features for one-to-one } \\
\text { content delivery (personalization model) } \\
\text { [22] }\end{array}$ & $\begin{array}{l}\text { Much more easier to implement } \\
\text { since it has only } 4 \text { models } \\
\text { better suited to represent the } \\
\text { requirements of a web } \\
\text { application. WebML has the } \\
\text { main disadvantage of not } \\
\text { supporting the use of use case } \\
\text { diagrams that are primarily } \\
\text { used to visualize the } \\
\text { interactions between the user } \\
\text { and the application. Use case } \\
\text { diagrams presented the } \\
\text { developers with a user friendly } \\
\text { way to explain the web } \\
\text { application to customers. }\end{array}$ \\
\hline $\begin{array}{l}\text { Web } \\
\text { Software } \\
\text { Architecture } \\
\text { (WebSA) }\end{array}$ & $\begin{array}{l}\text { WebSA is a Web model-driven approach } \\
\text { based on the Model Driven Architecture } \\
\text { (MDA) paradigm. It groups the Web } \\
\text { application model into three viewpoints: } \\
\text { requirements, functional, and } \\
\text { architectural viewpoints. The MDA- } \\
\text { based development process establishes } \\
\text { four phases of the development life } \\
\text { cycle: analysis; platform independent } \\
\text { design,; platform specific design, and } \\
\text { implementation [23] }\end{array}$ & $\begin{array}{l}\text { The methodology adds a new } \\
\text { architectural viewpoint } \\
\text { specifying a logical architecture } \\
\text { view and a physical } \\
\text { architecture view. This } \\
\text { viewpoint deals explicitly with } \\
\text { architectural issues. It is } \\
\text { considered as the main } \\
\text { contribution of the approach to } \\
\text { web application development. }\end{array}$ \\
\hline
\end{tabular}

Researchers and software developers are continuously proposing and experimenting with new methodologies to support web applications development. Table 3 provides only an overview of a few common methodologies and not a detailed analysis which is not the focus of this paper. 
International Journal of Software Engineering \& Applications (IJSEA), Vol.7, No.4, July 2016

Escalona and Koch [19] provide a more detailed analysis of web engineering methodologies and practices. Another comparative study of web methodologies was presented by Standing [18].

\subsection{GIS Development Methodologies}

GIS refers to the broad category of computing applications capable of creating, storing, manipulating, visualizing and analyzing geographic information [2]. Just like any information system, a GIS comprises of several major components as identified by Abbot et. al.[4]; A component to collect geographic data into the GIS either from remote sensing sources, field surveys, printed and digital maps, a database component that allows the storage and manipulation of spatial data and finally a presentation component that brings together themes or layers of data for a number of spatial analytical operations. A different view of the components of a GIS is provided by Harmon and Anderson [3].

Developing a GIS requires the developer to adopt a structured process that guarantees the system and user needs are met. These structured processes are methodologies in the context of software development. The methodologies follow some basic implementation process that applies to all GIS. They may differ on some technical backgrounds due to the nature of GIS implemented but the underlying approach is founded on a common development concept. Table 3 provides a summary of some common GIS development methodologies.

The focus of the methodologies in Table 3 is the enterprise GIS. According to Huxhold et. al.[24], Enterprise GIS refers to a system that is designed to meet the needs of multiple users. Such a system is built around a database that can be centralized or replicated across different machines. All presented methodologies can be summarized into the following generic steps;

- Conceptual Design/Needs assessment/Requirements gathering

- Logical Design - what does the system do?

- Physical Design - how will the systems do it?

- Implementation - getting the work done

- On-going System Management - operation and maintenance

Table 3: GIS Development Methodologies

\begin{tabular}{|l|l|}
\hline Author & Overview \\
\hline Somers [25] & The development is divided into 5 basic phases arranged in a waterfall \\
model with a feedback loop to the immediate preceding step; \\
$-\quad$ planning, \\
- analysis, \\
- design, \\
$\qquad$ acquisition and development, \\
\\
\\
Each phase is further defined and developed in successive steps that \\
compromise of feedback loops.
\end{tabular}


International Journal of Software Engineering \& Applications (IJSEA), Vol.7, No.4, July 2016

\begin{tabular}{|c|c|}
\hline $\begin{array}{l}\text { Harmon and } \\
\text { Anderson [3] }\end{array}$ & $\begin{array}{l}\text { Propose a more detailed methodology with multiple successive steps; } \\
\text { - Needs assessment/requirements analysis } \\
\text { - } \text { Implegic plan } \\
\text { - Design phase } \\
\text { - Implementation phase } \\
\text { - Pilot project } \\
\text { - Application development } \\
\text { - Upgrade and maintenance plans } \\
\text { - Evaluation } \\
\text { The methodology is relatively straightforward with minimal feedback } \\
\text { loops and decision points. However some steps are continuous. }\end{array}$ \\
\hline Longley [26] & $\begin{array}{l}\text { Methodology approaches GIS development as large IT projects that } \\
\text { are component based. There are } 4 \text { major lifecycle phases; } \\
\text { - Business planning - analysis and requirements elicitation } \\
\text { - System acquisition - purchasing system components } \\
\text { - System Implementation - assembling components to create an } \\
\text { integrated solution. } \\
\text { - operation and maintenance }\end{array}$ \\
\hline Tomlinson [27] & $\begin{array}{l}\text { More useful as a planning methodology with } 10 \text { steps to help you } \\
\text { determine your needs and implement a system to satisfy those needs. } \\
\text { The successive steps are; } \\
\text { - Determine strategic purpose } \\
\text { - } \text { plan for the planning } \\
\text { - conduct a technology seminar } \\
\text { - describe information products } \\
\text { - create a data design } \\
\text { - choose a logical model } \\
\text { - determine system requirements } \\
\text { - cost-benefit, migration and risk analysis }\end{array}$ \\
\hline
\end{tabular}




\subsection{Web GIS Development Methodologies}

Web GIS are slightly over a decade old with such systems gaining widespread popularity in the mid 2000s. The technology to support these systems has been rapidly evolving. We are now witnessing the adoption of open source tools and standards in the development of these systems. Unlike conventional software systems, methodologies for Web GIS have not been around for a very long time and some are project specific. There is a growing need for standardized approaches to the development of these systems. Few authors have published some methodologies that are presented in Table 4.

Table 4: Web GIS Development Methodologies

\begin{tabular}{|c|c|c|}
\hline Methodology & Overview & Strengths/Weaknesses \\
\hline $\begin{array}{l}\text { Web GIS } \\
\text { Development } \\
\text { Cycle } \\
\text { (Alesheikh } \\
\text { et.al.[28]) }\end{array}$ & $\begin{array}{l}\text { A hybrid approach adapted from the } \\
\text { waterfall model and the classical Software } \\
\text { Development Lifecycle (SDLC). } \\
\text { Development is split into } 8 \text { successive } \\
\text { phases in the following order; requirements } \\
\text { analysis, conceptual design, hardware \& } \\
\text { software survey, database design \& } \\
\text { construction, acquisition of GIS hardware \& } \\
\text { software, web GIS system integration, } \\
\text { application development and web GIS use } \\
\text { and maintenance. }\end{array}$ & $\begin{array}{l}\text { Suitable for the novice } \\
\text { developer as it offers a } \\
\text { simplified step by step } \\
\text { approach. However the } \\
\text { methodology is not } \\
\text { practical for large projects } \\
\text { and it does not put any } \\
\text { emphasis on user } \\
\text { involvement and testing } \\
\text { which are critical } \\
\text { components during the } \\
\text { development of such } \\
\text { systems. }\end{array}$ \\
\hline $\begin{array}{l}\text { Rapid GIS } \\
\text { Development } \\
\text { (Cavaco et. } \\
\text { al.[29]) }\end{array}$ & $\begin{array}{l}\text { Based on Rapid Application Development } \\
\text { methodology. Supports the rapid } \\
\text { development of database-centric GIS } \\
\text { applications. It is more of an implementation } \\
\text { framework than a methodology. }\end{array}$ & $\begin{array}{l}\text { The framework derives its } \\
\text { strength from its } \\
\text { underlying principles of } \\
\text { interoperability, } \\
\text { minimizing coding, } \\
\text { generalization of graphic } \\
\text { editing, auditing and } \\
\text { authentication. However } \\
\text { the framework is not } \\
\text { clearly defined with } \\
\text { clearly stated phases and } \\
\text { deliverables. What it } \\
\text { provides is a generalized } \\
\text { approach to web GIS } \\
\text { development. }\end{array}$ \\
\hline $\begin{array}{l}\text { Web GIS } \\
\text { Navigational } \\
\text { Development } \\
\text { Techniques } \\
\end{array}$ & $\begin{array}{l}\text { This process integrates models from } \\
\text { Navigational Development Techniques } \\
\text { (NDT) [31] methodology with models from } \\
\text { the Organizational Semiotic technique [32]. }\end{array}$ & $\begin{array}{l}\text { Supports the rapid } \\
\text { development of web GIS } \\
\text { applications. Furthermore } \\
\text { during the requirements }\end{array}$ \\
\hline
\end{tabular}


International Journal of Software Engineering \& Applications (IJSEA), Vol.7, No.4, July 2016

\begin{tabular}{|l|l|l|}
\hline $\begin{array}{l}\text { (NDT) } \\
\text { Methodology } \\
\text { (Escalona et } \\
\text { al.[30]) }\end{array}$ & $\begin{array}{l}\text { Consists of Requirements engineering, } \\
\text { conceptual design, navigational design, } \\
\text { abstract interface design and }\end{array}$ & $\begin{array}{l}\text { engineering, it introduces } \\
\text { the use of the } \\
\text { Organizational Semiotics } \\
\text { definitions to represent geographical } \\
\text { concepts. }\end{array}$ \\
& $\begin{array}{l}\text { to define requirements. } \\
\end{array}$ & \\
\hline
\end{tabular}

Web GIS development methodologies are still being developed as the number of such projects increases. The methodologies still require adequate testing on a broad range of projects. This is not entirely possible as GIS projects are quite costly and organizations may not be willing to risk adopting processes with a pure academic background.

\subsection{Choice of Web GIS Methodology}

As evidenced in the literature review, many development methodologies are in existence each suitable for different project scopes and domains. It was therefore necessary for the researchers to adopt a more formal approach while deciding which methodology to use. Avison and Fitzgerald [10] propose a checklist that can be employed by developers while selecting a methodology. Table 5 provides this list of evaluation criteria that was considered. Table 6 shows how each methodology scored against the criteria items.

Table 5: Methodology Selection Checklist

\begin{tabular}{|l|l|}
\hline Evaluation Criteria & Description \\
\hline Rules & $\begin{array}{l}\text { Does it provide clear formal guidelines to cover phases, } \\
\text { tasks and deliverables? }\end{array}$ \\
\hline Coverage & Does it cover the entire development process? \\
\hline Design & Does it separate physical and logical design? \\
\hline $\begin{array}{l}\text { Inter-stage } \\
\text { communication }\end{array}$ & Work should be communicable to other stages \\
\hline Teachable & Are the techniques in the methodology understandable? \\
\hline Designing for change & Can the designs be easily modified? \\
\hline $\begin{array}{l}\text { Simplicity and } \\
\text { pragmatic }\end{array}$ & Is it easy to use? \\
\hline Participation & Fostered through simplicity and good communication \\
\hline
\end{tabular}


Table 6: Cross Comparison of Web GIS Methodologies

\begin{tabular}{|c|c|c|c|}
\hline Evaluation Criteria & $\begin{array}{l}\text { Web GIS } \\
\text { Development Cycle }\end{array}$ & $\begin{array}{l}\text { Rapid GIS } \\
\text { Development }\end{array}$ & $\begin{array}{l}\text { Web GIS } \\
\text { Navigational } \\
\text { Development } \\
\text { Techniques } \\
\text { (NDT) } \\
\text { Methodology }\end{array}$ \\
\hline Rules & & & \\
\hline Coverage & & & \\
\hline Design & & & \\
\hline $\begin{array}{l}\text { Inter-stage } \\
\text { communication }\end{array}$ & & & \\
\hline Teachable & & & \\
\hline $\begin{array}{l}\text { Designing for } \\
\text { change }\end{array}$ & & & \\
\hline $\begin{array}{l}\text { Simplicity and } \\
\text { pragmatic }\end{array}$ & & & \\
\hline Participation & $X$ & X & \\
\hline
\end{tabular}

Vavpotic et. al.[33] suggest a more formal approach to evaluating the suitability of methodologies that involves examining the methodology from 2 dimensions; technical and social suitability. The technical dimension examines the technical characteristics which include; development team size, compatibility requirements, project scope, duration and type. The social dimension examines the social and cultural characteristics of the development team which include; experience, culture, innovativeness and team ethics. These two dimensions can be applied to formally decide the suitability of a development methodology to a software project. However this approach to methodology evaluation was inapplicable for this research because all the presented methodologies lacked documentation on the social aspects. Later on a more detailed framework by Avison and Fitzgerald [10] will be applied to evaluate the proposed methodology in the following section.

Having reviewed the existing methodologies for web, GIS and Web GIS projects, the researchers had to make a choice whether to adopt, adapt or build a methodology suitable for the current project. Table 6 shows the cross comparison results between the three Web GIS methodologies reviewed. It is clear that there is a need for a hybrid methodology that aggregates all the elements and emphasizes inter-stage communication while at the same time is simple enough and pragmatic for a novice user. The methodology should embrace the well tested approaches of conventional and web methodologies but at the same time accounts for the unique development activities typical in such systems. 
International Journal of Software Engineering \& Applications (IJSEA), Vol.7, No.4, July 2016

\subsection{Approach Used to Create Hybrid Methodology}

For the purpose of the research, a Software Process Improvement (SPI) model needed to be used for process improvement and evaluation so as to provide a structured approach to the proposed Web GIS methodology. Paulk et. al. [34] define a software process as " a defined as a set of activities, methods, practices, and transformations that people use to develop and maintain software and the associated products". The Capability Maturity Model Integration (CMMI) developed by Software Engineering Institute (SEI) at Carnegie Mellon University (CMU) was used. The initial Capability Maturity Model (CMM) was designed to guide process improvement strategies be examining current process maturity while identifying issues critical to software quality and process improvement. Through resolving this issues the overall software process can be improved leading to lasting gains in the software process capability [34,35]. Specifically the CMMI for Development consists of best practices addressing product and service development covering the entire lifecycle from conception to delivery and maintenance. Based on this, the CMMI-DEV, V1.3 [36] continuous representation was used as a baseline software process improvement model in developing the proposed methodology. This model was chosen mainly because it has gained international acceptance among the software engineering community and it is a comprehensive software improvement model that adheres to various international standards.

\section{Proposed Methodology}

The proposed methodology discussed in this paper is based on a blended approach to web development that uses both the iterative waterfall and classical SDLC as baseline software development methods. This choice is informed by the following reasons;

- The clients better understand the project because the approaches are structured and linear which require a full specifications to be developed prior to commencement.

- Both approaches emphasize the need for adequate planning with clear goals set before project launch which makes it easy to accurately estimate project budgets.

- Both approaches offer a definitive project progression path that emphasizes strict record keeping and allows for easy prediction of the final product.

- The iterations enable the solution to be better refined in order to meet the user needs.

- They are both applicable for small, medium-scale and less complex projects.

The methodology is referred to as the Y-Model Web GIS development methodology (YWDM). Figure 1 illustrates the main phases of the methodology. The development process is organized into three distinct sections; GIS development, Web application development and Integration \& Management. The proposed methodology appreciates that a Web GIS project produces a hybrid product that has qualities of both traditional GIS and web applications and hence it is important to fuse the best practices of each approach in order to achieve a sound product. The methodology has clearly defined phases with deliverables at the end of each phase including a feedback loop to previous phases in an attempt to introduce flexibility so as to accommodate user requirement changes. The details of the methodology phases are discussed in the following sub-sections; 
International Journal of Software Engineering \& Applications (IJSEA), Vol.7, No.4, July 2016

\subsection{Phase 1}

The initial stage in software development is problem definition which determines the scope of the problem. There are two activities that happen concurrently during this phase;

i.) Planning and Problem Definition- It is important to express the problem being solved with reference to its geographical relevance as the system to be developed has specific geospatial aspects to address. It is also important to develop an overall plan for the GIS development. The plans can be expressed through feasibility reports and detailed workflow diagrams.

ii.) Needs Assessment and Discovery- Web applications are interactive in nature and it is important to consider the end user needs during the initial phases. What are the user expectations of the system? This can be discovered through simple user surveys and focus group discussions with the intended end users of the system.

\subsection{Phase 2}

This is the analysis phase of the project. Concurrently you need to discover the functional and non-functional requirements of the GIS and web components. Various tools are used at this phase depending on the section you are addressing. GIS requirements can be discovered through discussions and interviews. Web requirements can also be discovered through structured interviews and questionnaires. It is important to examine the business processes that will be supported by the system you are delivering so that you can tailor make the system to address this needs. This phase results in a requirements specification document detailing the geographical and user requirements of the system.

\subsection{Phase 3}

Web applications are interactive applications. It is important to design the conceptual and navigation models of such a system. A conceptual model provides a summarized snapshot view of the overall system. It enables us to understand the main aspects of the system. This can be expressed through diagrammatic models. A web navigation model shows how the different web pages are linked together. UML-based web engineering provides us with the appropriate notation to express this model. Database design for the geodatabase to be used is also conducted at this phase. Relational models can still be used to express entities within the system.

\subsection{Phase 4}

This is a very important phase for the GIS development line. Data collection is conducted at this point using a variety of approaches namely field surveys, satellite data, use of GPS, survey maps, census data, aerial photographs and the wider PRA techniques. The collected data is then represented within the database schema designed earlier. The web pages can be coded using a scripting language. Various open source tools are available for use. However only the web page prototypes can be done as the final implementation is dependent on the data in the geodatabase. Most of the work on the web pages will be rendering and analyzing the geospatial data in the 
International Journal of Software Engineering \& Applications (IJSEA), Vol.7, No.4, July 2016

geodatabase. Unit testing is done on the web pages to check for errors at individual functional points.

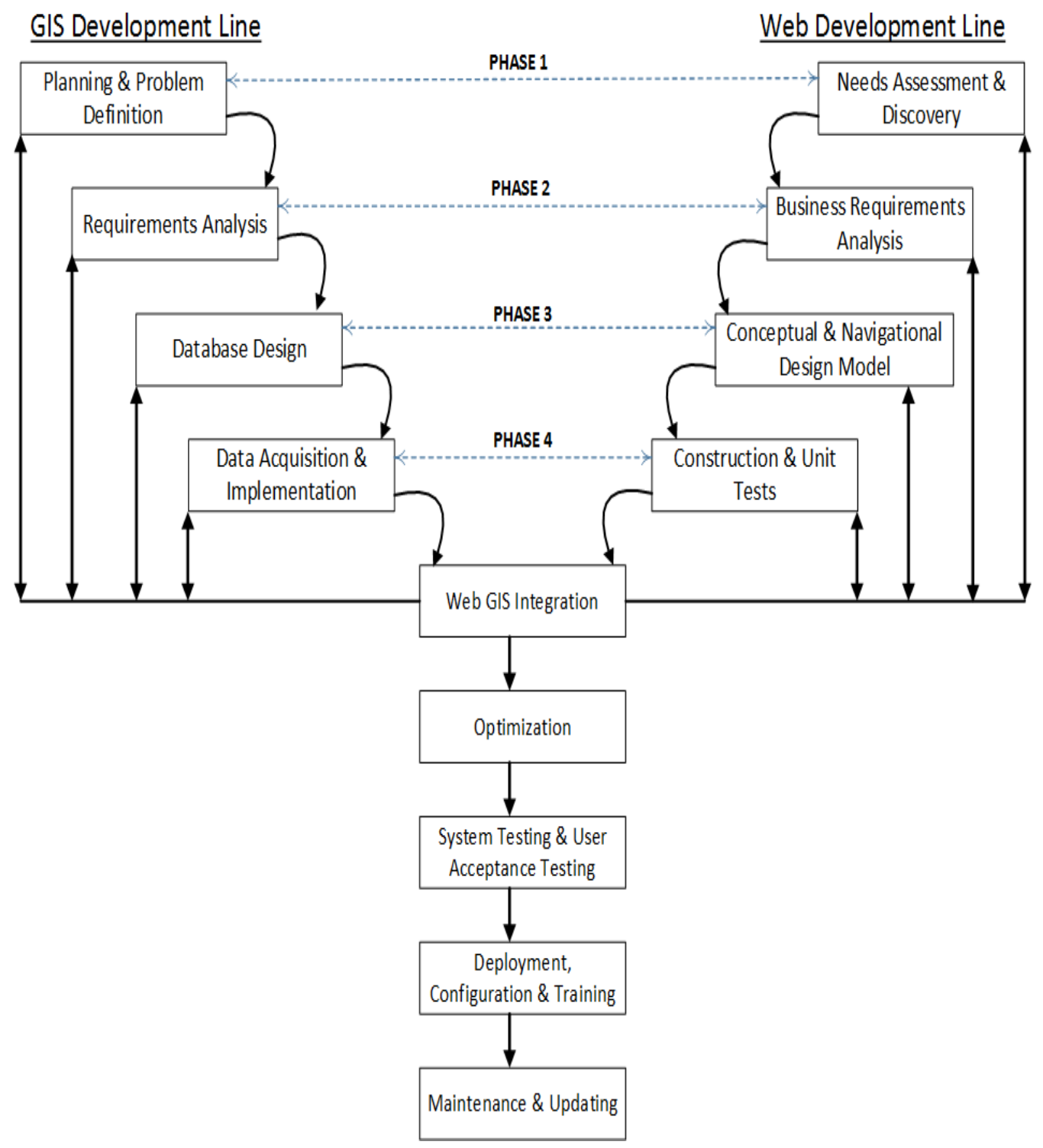

Figure 1: Y-Model Web GIS Development Methodology

\subsection{Phase 5 (Integration and Management Phase)}

This is the final phase and is the longest. Integration involves interfacing various system components so that they can work together. Integration testing is also conducted during this phase to check for compatibility issues and performance in general. The system will need to be 
International Journal of Software Engineering \& Applications (IJSEA), Vol.7, No.4, July 2016

optimized especially when serving the map layers. Different optimization techniques such as optimizing the tile cache are performed here to improve performance times. System testing is very important as the system is tested in its final operational environment which can be real or simulated depending on the developers access. The shift from development to operational environment during deployment and configuration can expose the system to various cases of incompatibilities. Users of the system are also afforded an opportunity to examine usability aspects of the system. This can be done through alpha and beta tests. The key here is to have as many users as possible participate in the process to reduce any potential resistance to the system. Maintenance is ongoing and will strive to accommodate any emerging needs.

\section{MeTHOdology Evaluation}

This paper adopts the framework proposed by Avison and Fitzgerald [10] to evaluate the proposed methodology. Currently it is very difficult to compare or evaluate methodologies as there are many views on methodologies as there are writers. However Avison and Fitzgerald [10] have devised a comprehensive framework that comprises of seven elements that can be used to evaluate/compare methodologies. These elements are;

i.) Philosophy - The principle or set of principles that underlies the methodology. It covers the paradigm, objective, domain and target.

ii.) Model - what constructs does the methodology use to model the real world?

iii.) Techniques and tools - what tools and techniques are provided to support the methodology user?

iv.) Scope - what phases of the development cycle does the methodology cover?

v.) Output - what are the main deliverables of the methodology and when are they generated?

vi.) Practice - does the methodology have a commercial or academic background? who are the main users of the methodology and what is their required technical competence?

vii.) Product - what does the methodology provide? software? documentation? training?

The following section presents details of the YWDM methodology in relation to the seven elements by Avison and Fitzgerald [10];

Table 7: YWDM Evaluation

\begin{tabular}{|l|l|}
\hline Element & Description \\
\hline Philosophy & $\begin{array}{l}\text { Paradigm- The methodology follows a science paradigm that belongs to } \\
\text { the objectivist approaches. } \\
\text { Objective- To build web driven geographical applications. } \\
\text { Domain- It is a problem solving methodology that is adapted to solving } \\
\text { specific pre-identified problems } \\
\text { Target- Small and medium organizations and suitable for geographical } \\
\text { web-based applications. }\end{array}$ \\
\hline Model & The methodology relies on process, data and object oriented models to \\
\hline
\end{tabular}


International Journal of Software Engineering \& Applications (IJSEA), Vol.7, No.4, July 2016

\begin{tabular}{|l|l|}
\hline & represent different aspects of the system. \\
\hline Techniques and & $\begin{array}{l}\text { The methodology provides a structured approach to systems } \\
\text { development. It does not recommend a specific set of tools as web } \\
\text { applications can be developed using a wide range of tools and } \\
\text { technologies. Data, process, object oriented and project management } \\
\text { techniques are applied. }\end{array}$ \\
\hline Scope & $\begin{array}{l}\text { The methodology covers the entire range of the systems development } \\
\text { lifecycle. These stages are; feasibility, analysis, logical design, physical } \\
\text { design, programming, testing, implementation and maintenance. }\end{array}$ \\
\hline Outputs & $\begin{array}{l}\text { Adopts the same approach as the classical SDLC by producing } \\
\text { document products at each significant milestone i.e. feasibility report, } \\
\text { requirements specification, design documents, test reports, system } \\
\text { documentation and implementation reports. }\end{array}$ \\
\hline Practice & $\begin{array}{l}\text { The methodology has an academic background. The main users of the } \\
\text { methodology would be programmers and analysts. Depending on the } \\
\text { system scope the role could be played by a single individual. Currently it } \\
\text { is still difficult to justify/evaluate the user base. }\end{array}$ \\
\hline Product & $\begin{array}{l}\text { The methodology is straight forward and intended to be used with } \\
\text { minimal training or consultations. Academic papers are available as } \\
\text { supporting documents. }\end{array}$ \\
\hline
\end{tabular}

\subsection{Unique Contribution}

Each Web GIS project has different goals and a unique set of problems and therefore the methodology chosen for the development will still require adaptation to the contingencies of each situation. The unique contribution of the proposed methodology is that it combines the milestonedriven easy to use approach of the iterative waterfall model with the classical, scalable and plandriven SDLC. The iterative loop introduced at the end of the cycle eliminates the earlier disadvantage of rigidity in the waterfall model. This makes it easy to deal with changing requirements by allowing previous completed steps to be revisited. Secondly the dual approach of the methodology enables different teams to simultaneously work on the two aspects of Web GIS development concurrently and allowing for an integration and testing of the system before final completion. It is hoped that the methodology proposed here will serve as a useful framework harnessing the technical skills and creative thinking of the Web GIS developer while retaining the simplicity desirable by both novice and expert developers.

\section{CONCLUSION}

The proposed Web GIS methodology is a theoretical model based on academic research and the authors experience with this type of applications and existing development methodologies. The methodology is an attempt to provide a structured approach to Web GIS development that can be widely adopted for both small and medium size projects. Its simplicity and similarity to existing approaches will make it a favourite for the novice developer. The methodology was applied to the development of the Emuhaya Web GIS Portal. The documentation that was produced as part of 
International Journal of Software Engineering \& Applications (IJSEA), Vol.7, No.4, July 2016

the project could not be presented in this paper due to space constraints. The portal can be accessed on www.emuhayawebgis.info. The methodology needs to be further tested on a number of projects so that empirical evidence can be collected to prove its success in aiding the development of Web GIS applications.

\section{REFERENCES}

[1] M. Adnan, A. Singleton, and P. Longley, "Developing efficient web-based GIS applications," UCL Work. Pap. Ser., vol. 44, no. 153, pp. 0-15, 2010.

[2] M. Goodchild, "The current status of GIS and spatial analysis", Journal of Geographical Systems, no.2, pp. 5-10, 2000.

[3] J.E. Harmon and S.J. Anderson, " The design and implementation of geographic information systems", John Wiley \& Sons, 2003.

[4] Jo. Abbot, R. Chambers, C. Dunn, T. Harris, E. Merode, G. Porter, J. Townsend and D. Weiner, " Participatory GIS: opportunity or oxymoron", PLA notes, Vol. 33, pp. 27-33, 1998.

[5] D.H. Kim and M.S. Kim, " Web GIS service component based on open environment", In Geoscience and Remote Sensing Symposium, IGARSS'02, 2002 IEEE International, vol. $\quad 6, \quad \mathrm{pp}$. 3346-3348, 2002.

[6] D. Lowe and B. Henderson-Sellers, "Characteristics of web development processes," Proc. SSGRR2001 Infrastructure for E-Business, E-Education and E-Science, pp. 1-12, 2001.

[7] Y. Deshpande, S. Murugesan, A. Ginige, S. Hansen, D. Schwabe, M. Gaedke, and B. White, "Web Engineering," Journal of Web Engineering, vol. 1, no. 1, pp. 3-17, 2002.

[8] S. Dragic'evic and S. Balram, "A Web GIS collaborative framework to structure and manage distributed planning processes," Journal of Geographical Systems., vol. 6, no. 2, pp. 133-153, 2004.

[9] D. Howcroft and J. Carroll, "A Proposed Methodology for Web Development.," European Conference on Information Systems, Vienna 2000 Proceedings, pp. 1-8, 2000.

[10] D. Avison and G. Fitzgerald, "Information systems development: methodologies, techniques and tools", McGraw Hill, 2006.

[11] J.M. Carey, " Prototyping: alternative systems development methodology", Information and Software Technology 32(2)", "Journal of Electronic Materials", Vol. 19, Issue 6, pp. 119-127, 1990.

[12] C. Ashworth and L. Slater, " An Introduction to SSADM Version 4", McGraw-Hill, 1993.

[13] B. Boehm and W. Hansen, "The Spiral Model as a Tool for Evolutionary Acquisition," CrossTalk, vol. 14, no. 5, pp. 4-11, 2001.

[14] R. Pressman, " Software Engineering: A Practitioner's Approach. 7th international edition", McGrawHill Education, New York (USA), 2009.

[15] A. French, "Web Development Life Cycle: A New Methodology for Developing Web Applications", Journal of Internet Banking and Commerce, vol. 16, no.2, 2011.

[16] A.S. Shaffi and M. Al-Obaidy, "Analysis and comparative study of traditional and web information systems development methodology (WISDM) towards Web development applications", International Journal of Emerging Technology and Advanced Engineering, 3(11), 277-282.

[17] C. Standing, "Methodologies for developing Web applications," Information and Software Technology., vol. $\quad 44$, no. 3, pp. 151-159, 2002.

[18] C. Standing, "The Requirements of Methodologies for Developing Web Applications," Proceedings of the Ninth

European Conference on Information Systems, Bled, Slovenia, June 27-29, pp. 548-557, 2001.

[19] M. J. Escalona and N. Koch, "Requirements engineering for web applications: a comparative study," Journal of Web Engineering, vol. 2, no. 3, pp. 193-212, 2003. 
International Journal of Software Engineering \& Applications (IJSEA), Vol.7, No.4, July 2016

[20] N. Koch, A. Knapp, G. Zhang, and H. Baumeister, "UML-based web engineering: An Approach Based on Standards," Web Engineering: Modeling and. Implementing Web Applications, pp. 157191, 2008.

[21] N. Koch and A. Kraus, " The expressive power of UML-based web engineering", In Second International Workshop on Web-oriented Software Technology (IWWOST02), Vol. 16, 2002.

[22] R. Shakuntla, A. Sharma and S. Sarangdevot," A Study on Modeling Standards for Web Applications and Significance of AspectWebML" , International Journal of Engineering Trends and Technology (IJETT), Vol. 4, Issue 6, 2013.

[23] S.M. Beigbeder and C.C. Castro, " An MDA approach for the development of web applications, In International Conference on Web Engineering, Springer Berlin Heidelberg, pp. 300-305, 2004.

[24] W.E. Huxhold, A.G. Huxhold and A.G. Levinsohn, Managing geographic information system projects. 1995.

[25] R. Somers, Quick Guide To Gis Implementation and Management. 2001.

[26] P. Longley, "Geographic information systems and science", John Wiley \& Sons, 2005.

[27] R.F. Tomlinson, " Thinking about GIS: geographic information system planning for managers", ESRI (Inc), 2007.

[28] A.A. Alesheikh., H. Helali and H.A. Behroz, "Web GIS: technologies and its applications", In ISPRS Technical Commission IV Symposium, Ottawa: Canada, Vol. 15, pp. 1-9, 2002.

[29] R. Cavaco, R. Sequeira, M. Araújo and M. Calejo, "Rapid GIS Development : a model- based approach focused on interoperability" ,In 13th AGILE International Conference on Geographic Information Science, Guimarães; Portugal, pp. 1-5, 2010.

[30] M. J. Escalona, A. Torres-zenteno, J. Gutierrez, E. Martins, R. S. Torres, and M. C. C. Baranauskas, "A Development Process for Web Geographic Information System A Case of Study”, Requirements Engineering, 2008.

[31] M.J. Escalona and G. Aragon, " NDT. A model-driven approach for web requirements", IEEE Transactions on Software Engineering, 34(3), pp. 377-390, 2008.

[32] K. Liu, " Semiotics in Information Systems Engineering", Cambridge University Press, Cambridge, 2000.

[33] D. Vavpotic, M. Bajec, and M. Krisper, "Measuring and Improving Software Development Methodology Value by Considering Technical and Social Suitability of its Constituent Elements," Advances in Theory, Practice and Education - Proceedings of the 13th International Conference on IS Development, Vilnius, Lithuania, Sept. 9-11, 2004, pp. 228-238, 2004.

[34] M.C. Paulk, B. Curtis, M.B. Chrissis and C.V. Weber, "Capability maturity model, version 1.1", IEEE software, 10(4), pp. 18-27, 1993.

[35] W.S. Humphrey, " Introduction to software process improvement". 1993.

[36] Team, CMMI Product, "CMMI® for Development, Version 1.3, Improving processes for developing better products and services." , Software Engineering Institute , 2010.

\section{ACKNOWLEDGEMENT}

We thank all the contributors and members of staff at the Geomatic Engineering and Geospatial Information Systems department of Jomo Kenyatta University of Agriculture and Technology, Nairobi, Kenya for their continued support throughput the duration of this study. 
International Journal of Software Engineering \& Applications (IJSEA), Vol.7, No.4, July 2016

\section{Authors}

Fanon Ananda is a PhD student in the department of Geomatic Engineering and Geospatial Information Systems department at Jomo Kenyatta University of Agriculture and Technology, Nairobi, Kenya. He has a first degree in Information Technology, Masters in Information Technology and his research interests are in the fields of software engineering and Geospatial Information Systems. He currently teaches in IT department in the same university.

Prof. David Kuria is the current Director of Land Management Information Systems at the National Lands Commission in the Ministry of Lands and Physical Planning of the Kenya government. He has a PhD in Civil Engineering (Tokyo University), M. Sc., Photogrammetry \& Geo-Informatics (Stuttgart University of Applied Sciences) and B. Sc. Surveying (University of Nairobi).

Dr. Moses Ngigi is a Senior Lecturer in the Institute of Geomatics and GIS, Dedan Kimathi University of Technology, Nyeri, Kenya. He has a PhD in Geoenvironmental Sciences (University of Tsukuba, Japan), M. Sc., Photogrammetry \& Geo-Informatics (Stuttgart University of Applied Sciences) and B. Sc. Surveying (University of Nairobi). 